\title{
ROLE OF OSMOPROTECTANTS AND SOIL AMENDMENTS FOR SUSTAINABLE SOYBEAN (Glycine max L.) PRODUCTION UNDER DROUGHT CONDITION: A REVIEW
}

\author{
${ }^{1}$ Department of Agronomy, Faculty of Agriculture, Kafrelsheikh University, Egypt \\ ${ }^{2}$ Wheat Research Center, Bangladesh Agricultural Research Institute, Dinajpur-5200, Bangladesh \\ ${ }^{3}$ Department of Agronomy, Hajee Mohammad Danesh Science and Technology University, Bangladesh \\ ${ }^{4}$ Department of Field Crops, Faculty of Agriculture, Cukurova University, Turkey \\ ${ }^{5}$ Agriculture department, The University of Swabi, Khyber Paktunkhwa Pakistan \\ ${ }^{6}$ Department of Agricultural Biology, Faculty of Agriculture, University of Ruhuna, Sri Lanka \\ ${ }^{7}$ Division of Crop Production, ICAR-Indian Institute of Pulses Research, Kanpur, Uttar Pradesh, India \\ ${ }^{8}$ Deapartment of Agronomy, Inistitute of Agricultural Sciences, BHU, Varanasi (UP)- 221 005, India \\ ${ }^{9}$ Institute of Field and Vegetable Crops, Maxim Gorky 30, Novi Sad, Serbia \\ ${ }^{10}$ Plant Nutritional Physiology Lab., Graduate School of Biosphere Science, Hiroshima University, Japan
}

Ayman EL Sabagh ${ }^{1 *}$, Akbar Hossain ${ }^{2}$, M.S. Islam ${ }^{3}$, C. Barutcular ${ }^{4}$, Shah Fahad ${ }^{5}$, D. Ratnasekera ${ }^{6}$, N. Kumar ${ }^{7}$, Ram Swaroop Meena ${ }^{8}$, Popović Vera ${ }^{9}$, H. Saneoka ${ }^{10}$

Received - August 14, 2017; Revision - December 07, 2017; Accepted - January 06, 2018

Available Online - February 20, 2018

DOI: http://dx.doi.org/10.18006/2018.6(1).32.41

\section{KEYWORDS \\ Compost \\ Glycine max \\ Osmoprotectants \\ Productivity \\ Tolerance \\ Water stress}

\begin{abstract}
Water stress has a significant effect on yield and quality of soybean through negatively influencing seedling establishment, growth, phenology and finally yield of soybean. The enhancement of soybean productivity and quality against water stress, application of proline, glycine betaine and soil application of compost play a vital role for improving the physiological processes. The current review highlights the physiological responses of soybean during various growth stages under water stress. Additionally, the review evaluates the mitigation mechanism of the adverse of water deficit stress on soybean through exogenous application of osmoprotectants as well as soil application of organic amendments. The study also tried to summarize the current understandings of exogenous application of osmoprotectants such asproline and glycine betaine, and soil amendments that could be used to minimize the harmful effect of water stress on seed yield and quality of soybean.
\end{abstract}

* Corresponding author

E-mail: ayman.elsabagh@agr.kfs.edu.eg (Ayman EL Sabagh)

Peer review under responsibility of Journal of Experimental Biology and Agricultural Sciences.

Production and Hosting by Horizon Publisher India [HPI] (http://www.horizonpublisherindia.in/).

All rights reserved.
All the article published by Journal of Experimental Biology and Agricultural Sciences is licensed under a Creative Commons Attribution-NonCommercial 4.0 International License Based on a work at www.jebas.org.

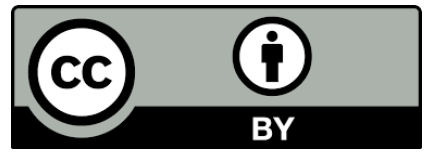




\section{Introduction}

Soybean (Glycine max) belongs to a leguminous family that grown for obtaining edible oil and forage. Seeds of soybean have a high content of proteins (40\%), lipids (20\%) and carbohydrates (Popović et al., 2015). It has been a good source of protein for human and animals feeding (Liu, 1997). Further, soybean seed oil is rich in essential fatty acids. Currently, it is considered as a potential plant to produce of biodiesel (Hill et al., 2006).

Growth, development, yield and end-product quality of a plant are highly influenced by environmental conditions, especially temperature and precipitation. (Meena et al., 2017; Islam et al., 2011; EL Sabagh et al., 2015h; Abdelaal et al., 2018). Among the environmental stress, Among the abiotic stresses, the drought has been identified as one of the principal global problems in future and will face a great challenge to crop production in worldwide especially in arid and semi-arid region (Barutcular et al., 2017). Similar to other susceptible crop, water stress is one of the major problems to limit the yield of soybean. Whereas water stress is one of the major problems to limit the yield of soybeanby changing different physiological and biochemical process of the plants during different growth stages (Farooq et al., 2009). Flowering and seed development stages of soybean are most sensitive to soil moisture stress (Popović et al., 2015). This can lead to a reduction in soybean grain yield up to $40 \%$ (Pathan et al., 2007; Popović et al., 2015). Some of the molecules like glycine, betaine and proline act as osmoprotectants (maintain osmotic pressure in plants) can be used to alleviate the unfavorable impacts of water stress under field condition (Hadiarto \& Tran, 2011; Thapa et al., 2011; Dadhich, et al., 2014).

Osmoprotectants can adding to plants in various ways i.e., through the rooting medium, foliar spray and pre-sowing seed treatment. Whereas, Ashraf \&Foolad, (2007) reported that foliar application of proline is more effective to alleviate the adverse effects of abiotic stresses than other application methods. Therefore, plant growth and development can be maintained with exogenous application of osmoprotectants under water deficit stress (drought) condition (Ashraf \& Foolad, 2007; Hadiarto \& Tran, 2011). Glycine betaine (GB), is pre-dominant in higher plants that synthesized in chloroplast from serine via ethanolamine, choline, and betaine aldehyde (Genard et al., 1991; Rhodes \& Hanson, 1993). It is a member of quaternary ammonium compound that plays a vital role for osmotic adjustment and protection of thylakoid membrane, thereby maintaining photosynthetic efficiency osmolytes under drought condition (Genard et al., 1991; Chaitanya et al., 2009). However, GB implementation has been taken as an approach to enhance the tolerance in plants under stress environments (Meena et al., 2016).

Incorporation of organic matter in soil has also a positive effect on growth, productivity, and yield of soybean (Ibrahim et al., 2008).
Application of compost derived from agricultural wastes can improve soil physical properties that maintain a supply of water and nutrients to plants for a longer period (Tejada et al., 2009). Compost is called as a soil conditioner that improves soil physicochemical properties such as water holding capacity and soil aeration (Patel et al., 1993), and serves as a source of plant nutrients (Campbell et al., 1986). Considering the above information, the current review aimed to clarify the physiological responses of soybean during various growth stages under drought conditions. Further more, the present review attempt to evalute the exogenous application of osmoprotectants and soil application of compost for the alleviation of adverse effects of water deficit stress on soybean and also for maximizing the yield of soybean.

\section{General perspectives of drought stress to soybean plant}

Water deficiency during plant growth and development is commonly known as a drought. It is one of the major environmental factors that is considered as a one of the limiting factor that limits the global crop production (Larcher, 2003; Centritto et al., 2008). According to Al-Barrak (2006), water stress has a significant effect on plant growth characters as well as seed and oil yields, however, seed oil content remains unaffected. Gaballah et al. (2008) and Ouda et al. (2008) reported the highest soybean yield and its components under irrigation using pan evaporation coefficient equal to 1.2. However, reduction in seed yield (3.3-3.4\%) was recorded when irrigation scheduled at pan evaporation coefficient of 1.0 and further reduction in seed yield (47.5-58.4\%) was recorded under pan evaporation coefficient of 0.8 . Tawfik (2008) also found a significant reduction in soybean yield under water stress treatments. Al-Suhaibani (2009) reported that soybean yield attributes, seed crude protein and carbohydrate content in the seed are highly correlated with soil water availability to plants. Photosynthetic pigment contents in relation to seed yield and yield contributing parameters of plants are fully depend on water and, macro and micronutrient nutrients uptake use efficiency (Alderfasi \& Alghamdi, 2010). Khalil \& Ismae (2010) reported significantly higher plant growth and relative leaf water content (RLWC) under sufficient soil moisture supply; however, water stress had a negative effect on these parameters. They also reported that the decreasing trend of soil moisture levels caused a significant increase in proline and alkaloids contents. Abdel \& Al-Rawi (2011) found that irrigation at every 8 days interval decreased growth and yield attributes, which ultimately reduced the soybean yield and seed yield per plant by 91.3 and $83.7 \%$. Irrigation scheduling at 10 and 20 days interval and water stress treatments revealed that reproductive stage is the most sensitive than vegetative stage causing a reduction in water-use efficiency and seed yield by at least $50 \%$ (Ahmed \& Suliman, 2010). Allahmoradi et al. (2011) found that both vegetative and reproductive stage respond similarly to water stress. However, the decrease in oil content was more when stress was imposed at flowering stage to stem elongation stage (Hosseini \& Hassibi, 2011). 


\section{Effect of water stress on soybean plants}

\subsection{Effect on Germination and seedling establishment}

Perfect, rapid and uniform germination is essential for having a good green area and crop growth rate for better radiation utilization and higher yield (Ashraf \& Mehmood, 1990). Germination period is more sensitive to water stress. At sowing time seeds generally, absorb water (50 percent of its weight) to begin germination. However, decrease in germination percentage and increase in germination time is observed under limited water supply or water stress (Willenborb et al., 2004). The percentage of germination and other traits related to germination are severely influenced by abiotic stress (Rasaei et al., 2013; EL Sabagh et al., 2015a.).The initiation of cell elongation during seed germination (McDonough, 1975) and seed vogour (Bayoumi et al., 2008) is very sensitive to water stress. Other researchers noticed that water deficit also induced osmotic stress and negatively influenced the growth of seedling (Djibril et al., 2005), although the exact potential inhibiting germination varied considerably under water stress conditions due to a smaller negative osmotic potential (Taylor et al., 1982). Comparative studies on the effect of different plant parts have showed that water stress reduced the linear growth of shoots while compared to those of unstressed plants (Kumar \& Sharma, 2009). The negative effect of water stress on plant growth/morphological parameters such as leaf area, number of leaves and tillers, and stem girth diameter have been well-documented by Abdalla \& El-Khoshiban, (2007).

\subsection{Effect on Plant growth and development}

The adverse effect of soil water stress was observed in RLWC, MSI, HI and DTI (Shinde et al., 2010). A significant decrease in chlorophyll $a$, chlorophyll $b$ and total chlorophyll contents were also recorded when water stress was imposed during vegetative or anthesis stage (Mafakher et al., 2010). They also observed the negative effect of water stress (drought) on photosynthesis, transpiration, stomatal conductance that ultimately reduced the yield of affected crop. Other researchers found significant reduction in dry matter accumulation, crop growth rate and relative growth rate as well as yield contributing characters i.e., grains per plant, grain filling duration and grain weight under water stress (Ghassemi-Golezani et al., 2009). During water stress root length of the sunflower genotypes was increased, while stem length, total leaf area, fresh and dry weights were decreased significantly that ultimately lead to reduce the total chlorophyll and carotenoid content, finally decreased the yield of sunflower(Manivannan et al., 2008). The decline in leaf area under water stress conditions is mainly attributed to declining in turgor pressure (Prasad et al., 2008). EL Sabagh et al. (2016a) observed that chlorophyll content of soybean plant decreased significantly under different level of water deficit conditions (Figure 1). Further, the previous results showed a negative impact on the growth parameters (EL Sabagh et al, 2015f). Yokas et al. (2008) observed that the reduction in leaf chlorophyll under drought stress condition is due to the destruction of chlorophyll pigments and instability of the pigment-protein complex. Similarly, water stress caused a reduction in $\mathrm{Chl} \mathrm{a,} \mathrm{Chl} \mathrm{b} \mathrm{and} \mathrm{carotenoid} \mathrm{contents} \mathrm{as} \mathrm{well}$ as the $\mathrm{Chl} \mathrm{a} / \mathrm{b}$ and carotenoid/Chl $\mathrm{a}+\mathrm{b}$ ratios in the leaves that ultimately lead to decrease the final yield (EL-Tayeb 2006). The alteration of chlorophyll might be an indicator in plants to understand the severity of environmental stresses (Barutçular et al. 2016a). They also found that water stress resulted in a decrease in RLWC and MSI and increase in lipid peroxidation level, catalase (CAT) and peroxidase (POX) activity. These led to decrease in photosynthesis rate and protein synthesis materials under water stress; therefore protein synthesis decreased drastically or even stops (Smiciklas et al., 1992). Under water deficit environments lipid peroxidation as malondialdehyde (MDA) significantly increased while decreasing catalyze and peroxidase activities (Abdelaal et al., 2017).

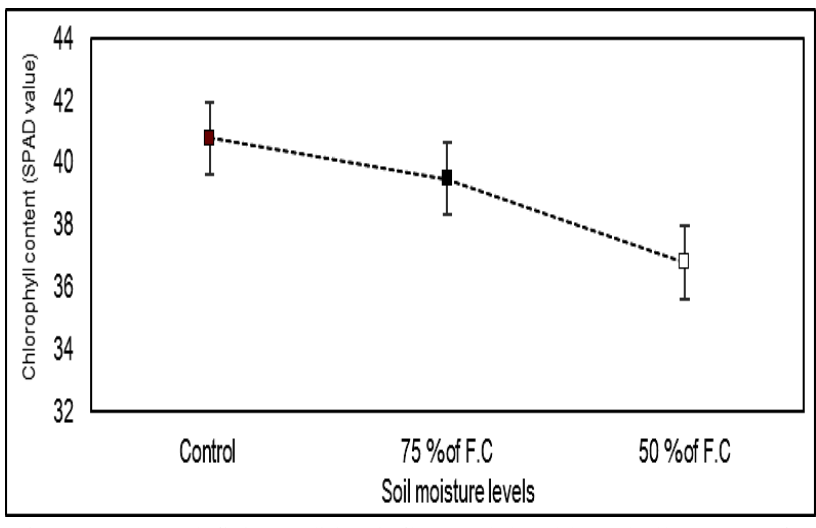

Figure 1 Water deficit condition influenced the chlorophyll content of soybean (F.C; field capacity). (Source: EL Sabagh et al., 2016a)

Inadequate water supply to plant, limits the productive potential due to a decrease in plant vegetative growth and reproductive period (Sibel \& Birol, 2007). Studies have indicated that leaf area growth decreased in response to water stress in many species of soybean (Zhang et al., 2004; Abdalla \& El-Khoshiban, 2007). EL Sabagh et al. (2016a) found that under different Water deficit condition (different field capacity level), chlorophyll content of soybean influenced significantly that lead to decrease the final seed yield of soybean (Figure $1 \& 2$ ).

\subsection{Effect on Biomass production}

The biomass production reduced with an increase in water deficit stress; nonetheless, in major cases, the tolerant genotypes had less reduction in biomass than susceptible ones (Salem, 2003). Water stress also inhibits partitioning of photo-assimilates within the 
plants (Bota et al., 2004). Environmental stresses led to significant reduction in growth parameters causing diminished crop productivity (Barutçular et al., 2016b; EL Sabagh et al., 2017; Rahman et al., 2017). Water stress during early grain development stage reduces the final grain dry matter (Khanna et al., 1994). Similarly, Sinaki et al. (2007) noticed that water stress during seed development stage reduces seed yield via reduction of seed weight. The yield and yield attributed traits have been significantly reduced by environmental stresses (Hossain et al., 2012a; Hossain et al., 2012b; Hossain et al., 2013; Hossain \&Teixeira da Silva, 2013; EL Sabagh et al., 2015a; EL Sabagh et al., 2015h; Hasan et al., 2017). Further, it is observed that water stress for short period during grain development stage decreases grain size and grain weight which ultimately affect the final grain yield. Water stress during early flowering stage increases death of floret and loss of seed size which resulted in reduction of harvest index (Seghatoleslami et al., 2008). Actually, water stress initiates a series of biochemical and physiological processes in plants which results in the reduction of crop yield (Shahbaz et al., 2011). The seed yield reduction of soybean due to water deficit stress was recently reported (EL Sabagh et al., 2016a \& Figure 2). Further, reduction of growth, yield and attributed traits of various crops have been well-documented (Abd el-wahed et al., 2015a; Abd el-wahed et al., 2015b; EL-Sabagh et al., 2015a: Barutçular et al. 2016c, EL Sabagh et al., 2017; Rashwan et al.,2016).

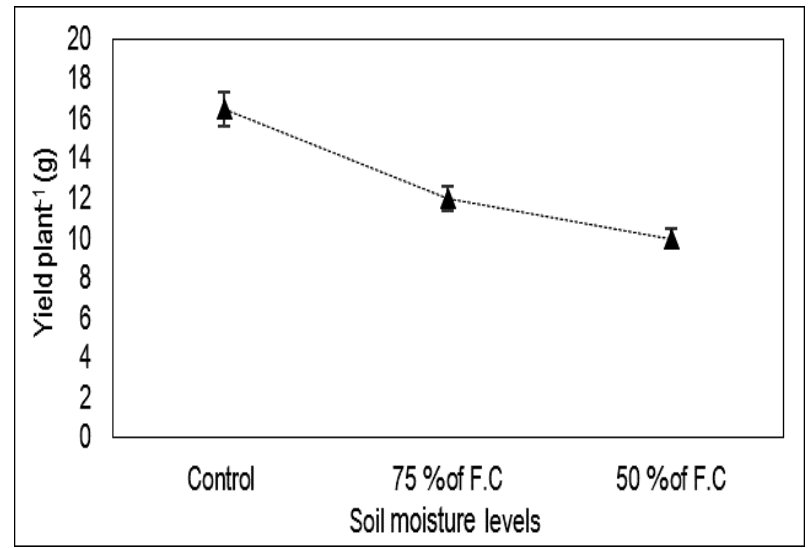

Figure 2 Influence of water deficit on yield plant ${ }^{-1}$ of soybean (Source: EL Sabagh et al., 2016a).

4 Strategies for managing environments stresses through bioregulatore and compost application

\subsection{Proline}

The enhancing of tolerance to stress environment of the plant is a viable strategies to find an answer to the problem induced by climate change, so, implementation of phytochemicals plays a vital role in improving stress tolerance in plants (Kazemi, 2014).
Hence, there are many defense mechanisms in plants such as osmoregulation, ion homeostasis, antioxidant and hormonal systems which induce the water stress tolerance in plants (Mahajan \& Tuteja, 2005). Many plants in dry habitats are known to accumulate organic solutes such as proline and glycine betaine (GB) (Khan \& Gul, 2006). Proline is a plant osmoregulator, whose accumulation is considered as an early response to water deficit stress (Ramanjulu \& Sudhakar, 2000). Proline accumulation plays an adaptive role in the plant to survive under stress condition (Verbruggen \& Hermans, 2008). Several investigators reported that proline plays a regulatory role in activity and function of the enzymes in plant cells and in their participation in the development of metabolic responses to environmental factors (Ozturk \& Demir, 2002). Similarly, these mechanisms are promoting photosynthesis, maintaining enzymatic activity and scavenging reactive oxygen species. Earlier studies noticed that the exogenous application of proline regulates uptake of mineral nutrients in plants subjected to water deficit conditions (Jaleel et al., 2007) and it is one of the osmotic protection mechanisms in the plant under water stress (Yamada et al., 2005).

Proline and GB are known to serve as compatible osmolytes, macromolecules protections and also as scavengers of ROS under stressful environments (Ashraf \& Foolad, 2007). Enhancement of proline concentration in whole plant organs is considered to be

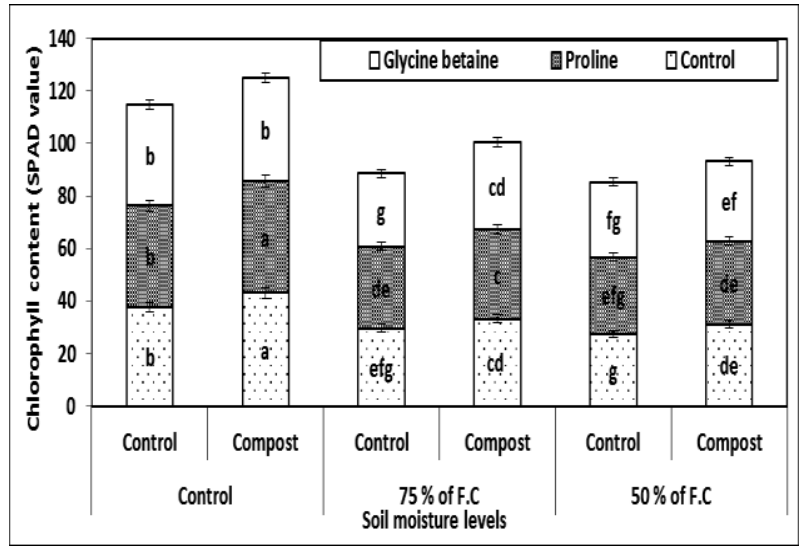

Figure 3 Effects of proline, glycine betaine and compost application on chlorophyll content in soybean under water stress (Source: EL Sabagh et al., 2015c).

correlated with water stress tolerance (Heikal \& Shaddad, 1982). However, the proposed functions of accumulated proline are osmoregulation, maintenance of membrane and protein stability under water stress condition (Taiz \& Zeiger, 2006; Wahba et al., 2007). It has been also observed that proline may protect chlorophyll damage (Figure 3) under water stress (EL Sabagh et al., 2015c). Much attention has been paid to define the role of proline in water stress tolerance as a compatible osmolyte (Samaras et al., 1995), which contributes in an osmotic adjustment 
in plant tissues (Bajji et al., 2000). However, little attention has been given to its role in affecting the uptake and accumulation of inorganic nutrients in plants (Khedr et al., 2003).

\subsection{Glycine betaine (GB)}

In a stressful environment, plants store multiple groups of compatible solutes such as sugars, free amino acids like glycine betaine (GB), proline and polyols to survive (Hoque et al., 2007). Chaitanya et al. (2009), GB is a member of quaternary ammonium compounds that are pre-dominant in higher plants subjected to water stress condition. It is one of the compatible solutes that play a significant role under drought condition for enhancing the productivity of soybean (EL Sabagh et al., 2015b; EL Sabagh et al., 2015d; EL Sabagh et al., 2015g; Figure 4).

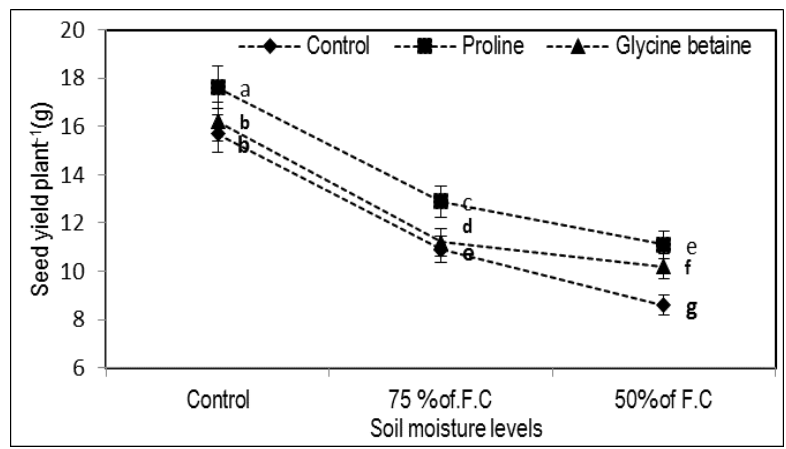

Figure 4 Effects of proline and glycine betaine application on seed yield/plant in soybean under water stress (Source: EL Sabagh et al., 2015b).

Further, Ibrahim \& Aldesuquy (2003) observed the protective role of GB in the growth and development of plant through osmotic adjustment where it acts as a non-toxic cytoplasmic osmolyte. Ashraf \& Foolad (2007) reported positive effects of exogenous application of GB on plant growth and final crop yield of soybean under water. Similarly, Mahmood et al. (2009), reported that application of GB at $50 \mathrm{mM}$ showed the maximum amelioration effect on growth under water stress by increasing shoot fresh biomass as well as leaf area per plant. While, GB did not influence the net $\mathrm{CO}_{2}$ assimilation rate, stomatal conductance, shoot and root $\mathrm{N}, \mathrm{K}^{+}, \mathrm{Ca}^{++}$and $\mathrm{P}$ and water use efficiency (Mahmood et al. 2009). Wang et al. (2010) reported that application of GB increased the osmotic adjustment in plants for water stress tolerance by improving antioxidative defense system including antioxidative enzymes in wheat crop. GB possesses anti-transparent properties which improve water stress tolerance in plants by reducing irrigation water requirements without sacrificing various quantitative indices (Agboma et al., 1997). Ali \& Ashraf (2011) found that exogenous application of GB ameliorate the negative effects of seed oil physicochemical attributes under water deficit conditions.

\subsection{Stress Management through compost application}

Balanced fertilization is an important factor to increase the productivity of agriculture. Addition of compost is essential to provide necessary nutrients for crops and improving soil physicochemical properties (Meena et al., 2015). The combined application of organic and inorganic fertilizers (INM) may reduce the demand for mineral fertilizer and soil degradation as well as save production cost. In addition, global environmental pollution can be also managed considerably by the reduction in the use of mineral fertilizer (Khaim et al., 2013). Compost application is one of the important practical measures to enhance seed yield under water stress condition as reported by EL Sabagh et al. (2015b; Figure 5). Further, it also improves soil microbial activities such as dehydrogenase and soil microbial biomass carbon (Sun et al., 2003).

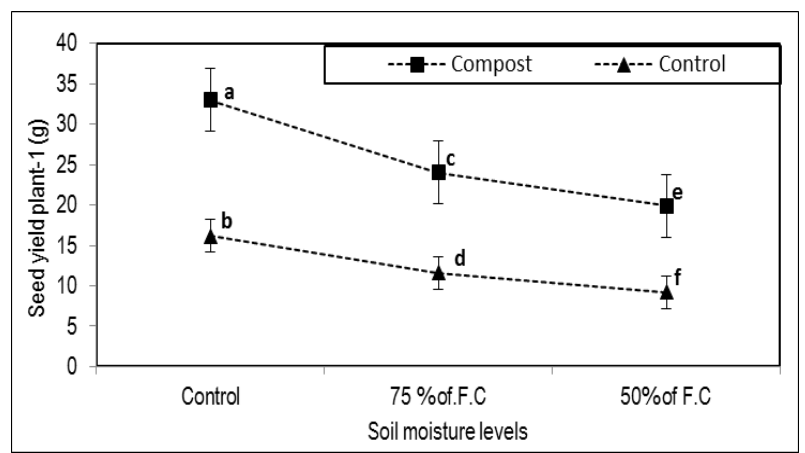

Figure 5 Effects of compost application on seed yield /plant in soybean under water stress (Source: EL Sabagh et al., 2015b).

An organic fertilizer like compost is considered as a soil conditioner and has potential to maintain higher soil moisture content for a longer period which in turn led to enhancement in crop growth and yield (Zhang et al., 2009). In addition, application of compost improves soil water-holding capacity and increases water and nutrients availability to plants (Wesseling et al., 2009). Enhancement in vegetative growth of sunflower under irrigation with different concentration of sea salt was recorded due to the application of vermicompost and biogas slurry (Ahmad \& Jabeen, 2009). However, the combined application of vermicompost and biogas slurry showed maximum benefits. Sayed et al. (2010) found the highest leaf relative water content (RLWC) of soybean by using $100 \%$ super absorbent polymer (200 $\mathrm{kg} / \mathrm{ha}$ ) under water stress. They also reported cell membrane stability (CMS) increased with increasing drought stress and decreased by using animal manure and super absorbent polymer. Further, the combined application of compost (FYM+NB) and proline exhibited the best results for enhancement in vegetative growth parameters, yield components and yield of wheat (ElSadek, 2005; Raafat et al., 2011). Bio-fertilizers also have a significant role in good yield and better utilization of water under 
stress condition (Rahimizadeh et al., 2007). The increase in plant growth parameters is positively associated with a quantity of compost applied to the soil (Sun et al., 2003; Chaturvedi et al., 2010). The potential influence of compost and organic matter on growth, productivity and quality of different crops under various environmental extremists was well understood (EL Sabagh et al., 2015b; EL Sabagh et al., 2015c; EL Sabagh et al., 2015e; EL Sabagh et al., 2016b; EL Sabagh et al., 2016c; EL Sabagh et al., 2016d; EL Sabagh et al., 2016e).

\section{Concluding Remarks}

In conclusion, this review demonstrated different responses of soybean plants to water stress. Water stress has an adverse effect on growth, physiology, yield, and quality of soybean. However, application of osmoprotectants and compost soil application of in soybean crop could be an alternative to improve the productivity of soybean under water stress condition. The study also confirms that the research related to water stress can solve the seasonal water stress problem to a greater extent and also provide the technical knowledge for sustainable agriculture development.

\section{Disclosure Statement}

Authors declare that no conflict of interest could arise

\section{References}

Abd El-Wahed MH, EL Sabagh A, Mohammed H, Ueda A, Saneoka $\mathrm{H}$, Celaleddin B (2015b) Evaluation of Barley Productivity and Water Use Efficiency under Saline Water Irrigation in Arid Region. International Journal of Agriculture Crop Science 8: 765-773.

Abd el-wahed MH, EL Sabagh A, Zayed A, Sanussi A, Saneoka H, Barutçular C (2015a) Improving yield and water productivity of maize grown under deficit-irrigated in dry area conditions. Azarian Journal of Agriculture 2: 123-132.

Abdalla MM, El-Khoshiban NH (2007) The influence of water stress on growth, relative water content, photosynthetic pigments, some metabolic and hormonal contents of Triticum aestivum cultivars. Journal of Applied Science and Research 3: 2062-2074.

Abdel CG, Al-Rawi IMT (2011) Response of mungbean (Vigna radiata L., Wilczek) to gibberellic acid (GA3) rates and varying irrigation frequencies. International Journal of Bioscience 1: 85-92.

Abdelaal AAK, Hafez YM, EL Sabagh A (2017) Ameliorative effects of abscisic acid and yeast on morpho-physiological and yield characters of maize (Zea mays L.) plants under water deficit conditions. Fresenius Environmental Bulletin 26: 7372-7383.

Abdelaal AAK, Omara IR, Hafez MY, Samar ME, EL Sabagh A (2018) Anatomical, Biochemical and Physiological Changes in Some Egyptian Wheat Cultivars Inoculated with Puccinia gramini $f$. $s p$. tritici. Fresenius Environmental Bulletin 27 : 296-305.
Agboma PC, Peltonen-Sainio P, Hinkkanen R, Pehu E (1997) Effect of foliar application of glycine betaine on yield components of drought-stressed tobacco plants. Experimental Agriculture 33: 345-352.

Ahmed FE, Suliman ASH (2010) Effect of water stress applied at different stages of growth on seed yield and water-use efficiency of Cowpea. Agriculture and Biology Journal of North America 1: 534-540.

Ahmad R, Jabeen N (2009) Demonstration of growth improvement in sunflower (Helianthus annuиs L.) by the use of organic fertilizers under saline conditions. Pakistan Journal of Botany 41:1373-1384.

Al-Barrak KM (2006) Irrigation Interval and Nitrogen Level Effects on Growth and Yield of Canola (Brassica napus L.). Scientific Journal of King Faisal University (Basic and Applied Sciences) 7: 87-103.

Alderfasi AA, Alghamdi SS (2010) Integrated Water Supply with Nutrient Requirements on Growth, Photosynthesis Productivity, Chemical Status and Seed Yield of Faba Bean. American-Eurasian Journal of Agronomy 3: 08-17.

Ali Q, Ashraf M (2011) Exogenously applied glycine betaine enhances seed and seed oil quality of maize (Zea mays L.) Under water deficit conditions. Environment Experimental Botany 71: 249259. doi:10.1016/j.envexpbot.2010.12.009.

Allahmoradi P, Mokhtar G, Shayesteh T, Shahrbanu T (2011) Physiological Aspects of Mungbean (Vigna radiata L.) in Response to Drought Stress. International Proceedings of Chemical, Biological and Environmental Engineering $9: 272-275$.

Al-Suhaibani NA (2009) Influence of Early Water Deficit on Seed Yield and Quality of Faba Bean under Arid Environment of Saudi Arabia. American-Eurasian Journal of Agriculture and Environmental Science 5: 649-654.

Ashraf M, Foolad MR (2007) Roles of glycine betaine and proline in improving plant abiotic stress resistance. Environmental and Experimental Botany 59: 207-216.

doi:10.1016/j.envexpbot.2005.12.006.

Ashraf M, Mehmood S (1990) Response of four brassica species to drought stress. Environment and Experimental Botany 30: 93-100. doi.org/10.1016/0098-8472(90)90013-T.

Bajji M, Lutts S, Kinet JM (2000) Physiological changes after exposure to and recovery from polyethylene glycol-induced water deficit in callus cultures issued from durum wheat (Triticum durum Desf.) cultivars differing in drought resistance. Journal of Plant Physiology 156: 75-83. doi.org/10.1016/S0176-1617(00)80275-8.

Barutçular C, EL Sabagh A, Konuskan O, Saneoka H and Yoldash KM (2016a) Evaluation of maize hybrids to terminal drought stress tolerance by defining drought indices. Journal of Experimental Biology and Agricultural Sciences 4: 610- 616.

Barutçular C, EL Sabagh A, Koç M, Ratnasekera D (2017) Relationships between Grain Yield and Physiological Traits of Durum Wheat Varieties under Drought and High Temperature Stress in Mediterranean Conditions. Fresenius Environmental Bulletin 26: (17_00433). 
Barutçular C, Yıldırım M, Koç M, Akıncı C, Tanrıkulu A, EL Sabagh A, Saneoka H, Ueda A, Islam MS, Toptas I, Albayrak O, Tanrikulu A (2016b) Quality traits performance of bread wheat genotypes under drought and heat stress conditions. Fresenius Environmental Bulletin 25: 6159-6165

Barutçular C, Yildirim M, Koc M, Akinci C, Toptac I, Albayrak O, Tanrikulu A, ELSabagh A (2016c) Evaluation of SPAD chlorophyll in spring wheat genotypes under different environments. Fresenius Environmental Bulletin 25: 1258-1266.

Bayoumi YT, Manal HE, Ehab MR (2008) Application of physiological and biochemical indices as a screening technique for drought tolerance in wheat genotypes. African Journal of Biotechnology 7: 2341-2352.

Bota AJ, Medrano H, Felxas J (2004) Is photosynthesis limited by decreased rubisco activity and RuBP content under progressive water stress? New Phytologyst 162: 671-681.doi: 10.1111/j.14698137.2004.01056.x

Campbell CA, Schnitzer M, Stewart JWB, Biederbeck YO, Selles F (1986) Effect of manure and P fertilizer on properties of a black chernozem in southern Saskatchewan. Canadian Journal of Soil Science 66: 601-613. doi.org/10.4141/cjss86-060.

Centritto M, Lauteri M, Monteverdi MC, Serraj R (2008) Leaf gas exchange, carbon isotope discrimination, and grain yield in contrasting rice genotypes subjected to water deficits during the reproductive stage. African Journal of Biotechnology 7: 2341-2352.

Chaitanya KV, Rasineni GK, Reddy AR (2009) Biochemical responses to drought stress in mulberry (Morus alba L.): evaluation of proline, glycine betaine and abscisic acid accumulation in five cultivars. Acta Physiologiae Plantarum 31: 437-443. DOI 10.1007/s11738-008-0251-6.

Chaturvedi S, Chandel AS, Dhyani VC, Sing AP (2010) Productivity, profitability and quality of soybean (Glycine $\max \mathrm{L}$.) and residual soil fertility as influenced by integrated nutrient management. Indian Journal of Agronomy 55: 133-137.

Dadhich RK, Reager ML, Kansoti BC, Meena RS (2014) Efficacy of Growth Substances on Mustard (Brassica juncea L.) under Hyper Arid Environmental Condition of Rajasthan. The Ecoscan 8 : 269-272.

Djibril S, Mohamed OK, Diago D, Diegane D, Abaye BF, Maurice S, Alain B (2005) Growth and development of data palm (Phoenix dactylifera L.) seedling under drought and salinity stress. African Journal of Biotechnology 4: 968-972.

EL Sabagh A, Omar A, Saneoka H, Barutçular C (2015a) Physiological performance of soybean germination and seedling growth under salinity stress. Dicle University Inst. Natural Applied Science Journal 4: 6-15

EL Sabagh A, Sorour S, Omar A, Islam MS, Ueda A, Saneoka H, Barutçular C, (2015b) Soybean (Glycine max L.) growth enhancement under water stress conditions. International Conference on Chemistry Agriculture and Biological Science (CABS-2015) Sept. 4-5, 2015 Istanbul (Turkey).
EL Sabagh A, Sorour S, Omar A, Islam MS, Ueda A, Saneoka H, Barutçular C (2015c) A comparative study on role of proline, glycine betaine and compost fertilizer in improving drought stress resistance of soybean. 2nd International Conference on Sustainable Agriculture and Environment, Konya, Turkey.

EL Sabagh A, Sorour S, Omar A, Ragab A, Islam MS, Barutçular C, Ueda A, Saneoka H (2015d) Alleviation of Adverse Effects of Salt Stress on Soybean (Glycine max L.) by Using Osmoprotectants and Compost Application. International Journal of Biological, Biomolecular, Agricultural, Food and Biotechnological Engineering 9 :1014-1018.

EL Sabagh A, Omar A, Saneoka H, Barutçular C (2015e) Evaluation agronomic traits of canola (Brassica napus $\mathrm{L}$.) under organic, bio- and chemical fertilizers. Dicle University Institute of Natural and Applied Science Journal 4:59-67.

EL Sabagh A, Omar A, Saneoka H, Barutçular C (2015f) Comparative physiological study of soybean (Glycine max L.) cultivars under salt stress. Yuzuncu Yil University Journal of Agricultural Sciences $25: 269-278$

EL Sabagh A, Islam MS, Ueda A, Saneoka H, Barutçular C (2015g) Increasing reproductive stage tolerance to salinity stress in soybean. International Journal of Agriculture and Crop Science 8: 738-745.

El-Sabagh A, Sorour S, Ueda A, Saneoka H, Barutçular C (2015h) Evaluation of salinity stress effects on seed yield and quality of three soybean cultivars. Azarian Journal of Agriculture 2: 138-141.

EL Sabagh A, Sorour S, Morsi A, Islam MS, Ueda A, Barutcular C, Arioglu H, Saneoka H (2016a) Role of osmoprotectants and compost application in improving water stress tolerance in soybean (Glycine $\max$ L.). International Journal of Current Research 8: 25949-25954.

EL Sabagh A, Abdelhamid O, Saneoka H, Islam MS (2016b) Roles of compost fertilizer on nitrogen fixation in soybean (Glycine $\max \mathrm{L}$.) under water deficit conditions. Agricultural Advances 5: 340-344. DOI: $10.14196 /$ aa.v5i7.2326.

EL Sabagha A, Sorour S, Saneoka H, Islam MS (2016c) Enhancing nitrogen fixation in soybean (Glycine max L.) by composting under saline stress condition. Agricultural Advances 5: 345-348. DOI: 10.14196/aa.v5i8.2327.

EL Sabagh A, Abd El-Rasool S, Islam MS, Barutçular C, Omar A (2016d) Improving growth of canola (Brassica napus L.) plants by seed inoculation and inorganic - organic nitrogen fertilization. Asian Journal of Science and Technologies 7: 2283- 2288.

EL Sabagh A, Omar A, Saneoka H, Barutçular C (2016e) Role of integrated use of nitrogen fertilizer sources in improving seed quality of canola (Brassica napus L.). Turkish Journal of Agriculture-Food Science and Technology 4:73-78.

EL Sabagh AE, Sorour S, Ragab A, Saneoka H, Islam MS (2017) The effect of exogenous application of proline and glycine betaine on the nodule activity of soybean under saline condition. Journal of Agricultural Biotechnology 2: 01-05. DOI: 10.20936/JAB/160301. 
El-Sadek AN (2005) Effect of some agronomic practices on sunflower productivity in new valley. M.Sc Thesis submitted to the Faculty of Agriculture, Ain Shams University, Egypt.

El-Tayeb AM (2006) Differential responses of pigments, lipid peroxidation, organic solutes, catalase and peroxidase activity in the leaves of two Vicia faba L. cultivars to drought. International Journal of Agricultural Biology 8: 116-122.

Farooq M, Wahid A, Kobayashi N, Fujita D, Basra SMA (2009) Plant drought stress: effects, mechanisms and management. Agronomy and Sustainable Development 29:185-212.DOI: 10.1051/agro: 2008021.

Gaballah MS, OudaSamiha A, Khalil FA (2008) effect of water stress on the yield of soybean and maize grown under different intercropping patterns. $12^{\text {th }}$ International Water Technology Conference, IWTC12 2008, Alexandria, Egypt, 611-624.

Genard H, Le Saos J, Hillard J, Tremolieres A, Boucaud J (1991) Effect of salinity on lipid composition, glycine betaine content and photosynthetic activity in chloroplasts of Suaeda maritime. Plant Physiology and Biochemistry 29:421-427.

Ghassemi-Golezani K, Ghanehpoor S, Dabbagh Mohammadi-Nasab A (2009) Effects of water limitation on growth and grain filling of faba bean cultivars. Journal of Food, Agriculture and Environment 7: 442-447.

Hadiarto T, Tran LSP (2011) Progress studies of drought responsive genes in rice. Plant Cell Reports 30: 297-310. DOI: 10.1007/s00299010-0956-z.

Hasan MDK, EL Sabagh A, Sikdar MDSI, Alam MDJ, Ratnasekera D, Barutçular C, Islam MS (2017) Comparative adaptable agronomic traits of black gram and mungbean for saline lands. Plant Archives 17:589-593.

Heikal MM, Shaddad MA (1982) Alleviation of osmotic stress on seed germination and seedling growth of cotton, pea and wheat by proline. Phyton 22: 275-287.

Hill J, Nelson E, Tilman D, Polasky S, Tiffany D (2006) Environmental, economic, and energetic costs and benefits of biodiesel and ethanol biofuels. Proceedings of the National Academy of Sciences 103: 11206-11210.

Hoque MA, Banu MNA, Okuma E, Amako K, Nakamura Y, Shimoishi Y, Murata Y, (2007) Exogenous proline and glycine betainein cresses $\mathrm{NaCl}$-induced ascorbate glutathione cycle enzyme activities and proline improves salt tolerance more than glycine betaine in tobacco Bright yellow-2 suspension- cultured cells. Journal of Plant Physiology 164: 553-561.DOI: 10.1016/j.jplph.2006.10.004.

Hosseini SM, Hassibi P (2011) Effects of Water Deficit Stress on Several Quantitative and Qualitative Characteristics of Canola (Brassica napus L.) Cultivars. Notulae Scientia Biologicae 3: 120125. doi.org/10.15835/nsb336135.

Hossain A, Teixeira da Silva JA (2013) Wheat production in Bangladesh: its future in the light of global warming. AoB Plants 5: pls042. doi: 10.1093/aobpla/pls042

Hossain A, Teixeira da Silva JA, Lozovskaya MV, Zvolinsky VP (2012a) High temperature combined with drought affect rainfed spring wheat and barley in South-Eastern Russia: I. Phenology and growth. Saudi Journal of Biological Sciences 19 : 473-487.

Hossain A, Teixeira da Silva JA, Lozovskaya MV, Zvolinsky VP, Mukhortov VI (2012b) High temperature combined with drought affect rainfed spring wheat and barley in south-eastern Russia: yield, relative performance and heat susceptibility index. Journal of Plant Breeding and Crop Science 4 : 184-196.

Hossain A, Sarker MAZ, Saifuzzaman M, Teixeira da Silva JA, Lozovskaya MV, Akhter MM (2013) Evaluation of growth, yield, relative performance and heat susceptibility of eight wheat (Triticum aestivum L.) genotypes grown under heat stress. International Journal of Plant Production 7 : 615-636.

Ibrahim KA, Elsheikh EAE, Babiker EE (2008) Minerals composition of soybean (Glycine max L.) seeds as influenced by Bradyrhizobium inoculation and chicken manure or sulphur fertilization. Pakistan Journal of Nutrition 7: 793-800

Ibrahim AH, Aldesuquy HS (2003) Glycine betaine and shikimic acid induced modification in growth criteria, water relation and productivity of droughted Sorghum bicolor plants. Phyton (Horn, Austria) 43: 351-363.

Islam MS, Akhter MM, EL Sabagh A, Liu LY, Nguyen NT, Ueda A, Masaoka Y, Saneoka H (2011) Comparative studies on growth and physiological responses to saline and alkaline stresses of Foxtail millet (Setaria italica L.) and Proso millet (Panicum miliaceum L.). Australian Journal of Crop Science 5: 1269- 1277

Jaleel CA, Gopi R, Manivannan P, Panneerselvam R (2007) Responses of antioxidant defense system of Catharanthus roseus [L.] to paclobutrazol treatment under salinity. Acta Physiologiae Plantarum 29: 205-209.

Kazemi M (2014) Effect of foliar application with salicylic acid and methyl jasmonate on growth, flowering, yield and fruit quality of tomato. Bulletin of Environment, Pharmacology and Life Sciences 3: 154-158.

Khaim S, Chowdhury MAH, Saha BK (2013) Organic and inorganic fertilization on the yield and quality of soybean. Journal of Bangladesh Agricultural University 11: 23-28.

Khalil ES, Ismae EG (2010) Growth, Yield and Seed Quality of Lupinustermis as Affected by Different Soil Moisture Levels and Different Ways of Yeast Application. Journal of American Science 6:141-153.

Khan MA, Gul B (2006) Halophyte seed germination. In: Khan MA, Weber DJ (Eds). Ecophysiology of high salinity tolerant plants. Springer Publications, Netherlands Pp. 11-30.

Khanna CR, Rao PSS, Maheswar M, Aobing L, Sbaivchankar KS (1994) Effect of water deficit on accumulation of dry matter carbon and nitrogen in the kernel of wheat genotypes differing in yield stability. Annals of Botany 74: 503- 511. https://doi.org/10.1006/anbo.1994.1147.

Khedr AHA, Abbas MA, Wahid AAA, Qauick WP, Abugadallah GM (2003) Proline induces the expression of salt stress responsive proteins and may improve the adaptation of PancratiummaritimumL., to alt 
stress. Journal of Experimental Botany 54: 2553-2562. DOI: 10.1093/jxb/erg277.

Kumar A, Sharma KD (2009) Physiological responses and dry matter partitioning of summer Mungbean (Vigna radiata L.) genotypes subjected to drought conditions. Journal of Agronomy and Crop Sciences 195: 270-277. DOI: 10.1111/j.1439-037X.2009.00373.x.

Larcher W (2003) Physiological Plant Ecology: Eco-physiology and Stress Physiology of Functional groups. Springer, New York.

Liu KS (1997) Soybean chemistry technology and utilization. Chapman and Hall, New York. ISBN. 0-412-08121-0.

Mafakheri A, Siosemardeh A, Bahramnejad B, Struik PC, Sohrabi E (2010) Effect of drought stress on yield, proline and chlorophyll contents in three chickpea cultivars. Australian Journal of Crop Science 4:580-585.

Mahajan S, Tuteja N (2005) Cold, salinity and drought stresses: An overview. Archive of Biochemistry and Biophysics 44: 139-158. DOI: 10.1016/j.abb.2005.10.018.

Mahmood T, Ashraf M, Shahbaz M (2009) Does exogenous application of glycine betaine as a pre-sowing seed treatment improve growth and regulate some key physiological attributes in wheat plants grown under water deficit conditions? Pakistan Journal of Botany 41: $1291-1302$.

Manivannan P, Jaleel CA, Somasundaram R, Pannerselvam R (2008) variation in Growth and Pigment Compositon of Sunflower Varieties under Early Season Drought Stress. Global Journal of Molecular Sciences 3: 50-56.

McDonough WT (1975) Water potential of germination seeds. Botanical Gazette 136: 106-108.

Meena RS, Kumar V, Yadav GS, Mitran T (2017) Response and interaction of Bradyrhizobium japonicum and Arbuscular mycorrhizal fungi in the soybean rhizosphere: A review. Plant Growth Regulation. DOI 10.1007/s10725-017-0334-8

Meena H, Meena RS, Singh B, Kumar S ( 2016) Response of bioregulators to morphology and yield of clusterbean [Cyamopsis tetragonoloba (L.) Taub.] under different sowing environments. Journal of Applied and Natural Science 8 :715-718.

Meena RS, Meena VS, Meena SK, Verma JP ( 2015) The needs of healthy soils for a healthy world. Journal of Cleaner Production102:560-561

Ouda SAE, Mohamed SG, Khalil FA 2008) Modeling the effect of different stress conditions on maize productivity using yield-stress model. International Journal of Natural and Engineering Sciences 2: 57-62.

Ozturk L, Demir Y (2002) In Vivo and in Vitro Protective Role of Proline. Plant Growth Regulation 38: 259-264. DOI: http://dx.doi.org/10.1023/A:1021579713832.

Patel, MS, Gundalia JD, Polara KB, Patel AG (1993) Effect of depth and frequency of saline well water irrigation and FYM on yield of wheat maize-groundnut/paddy cropping sequence on two calcareous sodic soils of coastal belt. Gujarat Agriculture University Research Journal 18: 40-48.

Pathan MS, Lee JD, Shannon JG, Nguyen HT (2007) Recent advances in breeding for drought and salt stress tolerance in soybean. In: Jenks MA, Hasegawa PM, Jain SM (Eds), Advances in molecu-lar breeding toward drought and salt tolerant crops. Springer Netherlands Pp. 739773 .

Popović V, Miladinović J, Vidić M, Vučković S, Dolijanović Ž, Ikanović J, Živanovic L, Kolarić L (2015) Drought Limiting factors in soybean production. The effect of irrigation on yield of soybean [Glycine max (L.) Merr.]. Journal of Institute of PKB Agroekonomik, Belgrade 21: 11-21. DOI: 10.13140/RG.2.1.1596.0808.

Prasad PVV, Staggenborg SA, Ristic Z (2008) Impacts of drought and/or heat stress on physiological, developmental, growth, and yield processes of crop plants. Response of crops to limited water: Understanding and modeling water stress effects on plant growth processes, (response of crops), pp. 301-355.

Raafat N, Zaki, Tharwat EE, Radwan (2011) Improving Wheat Grain Yield and Its Quality under Salinity Conditions at a Newly Reclaimed Soil by Using Different Organic Sources as Soil or Foliar Applications. Journal of Applied Sciences Research 7: 42-55. DOI: https://doi.org/10.1016/j.plantsci.2003.08.018.

Rahimizadeh M, Habibi D, Madani H, Mohammadi GN, Mehraban, Sabet A (2007) The effect of micronutrients on antioxidant enzymes metabolism in sun flower ( Helianthus annuusL.) under drought stress. Helia 30: 167-174.DOI: 10.2298/HEL0747167R.

Rahman MM, Zahan F, Sikdar MSI, EL Sabagh A, Barutçular C, Islam MS, Ratnasekera D (2017) Evaluation of salt tolerance mungbean genotypes and mitigation of salt stress through potassium nitrate fertilization. Fresenius Environmental Bulletin 26(12/2017): 7218-7226.

Ramanjulu S, Sudhakar C (2000) Proline metabolism during dehydration in two mulberry genotypes with contrasting drought tolerance. Journal of Plant Physiology 157:81-85. doi.org/10.1016/S0176-1617 (00)80139-X.

Rasaei B, Mohammad-Eghbal G, Maryam KA, Mokhtar G (2013) Effect of osmotic potential on germination and seedling characteristics of soybean seeds. International Journal of Agriculture and Crop Sciences 5: 1265-1268.

Rashwan E, Mousa A, EL-Sabagh A, Barutçular C (2016) Yield and Quality Traits of Some Flax Cultivars as Influenced by Different Irrigation Intervals. Journal of Agricultural Science 8: 226-240. doi.org/10.5539/jas.v8n10p226.

Rhodes D, Hanson AD (1993) Quaternary ammonium and tertiary sulfonium compound in higher plant. Annual Review of Plant Physiology Plant Molecular Biology 44: 357-384.

Salem M (2003) Response of durum and bread wheat genotypes to drought biomass and yield components. Asian Journal of Plant Science 2: 290-93. doi: 10.3923/ajps.2003.290.293.

Samaras Y, Bressan RA, Csonka LN, Garci a-Rios MG, Paino D, Urzo M, Rhodes D (1995) Proline accumulation during drought and 
salinity. In: Smirnoff N (Ed), Environment and Plant metabolism. Bios Scientific publishers, oxford, Pp. 161-187.

Sayed AK, Mohammad G, Mahmod R, Sayed RM, Mohammad JR, Parviz R-M (2010) Effect of animal manure and superabsorbent polymer on corn leaf relative water content, cell membrane stability and leaf chlorophyll content under dry condition. Australian Journal of Crop Science 4:642-647.

Seghatoleslami MJ, Kafi M, Majidi E (2008) Effect of drought stress at different growth stages on yield and water use ef- ficiency of five proso millet (Panicum miliaceum L.) genotypes. Pakistan Journal of Botany 40: 1427-1432.

Shahbaz M, Masood Y, Parveen S, Ashraf M (2011) Is foliar applied glycinebetaine effective in mitigating the adverse effects of drought stress on wheat (Triticum aestivum L.)? Journal of Applied Botany and Food Quality 84: 192-199.

Shinde BM, Limaye AS, Deore GB, Laware SL (2010) Physiological responses of groundnut varieties to drought stress. Asian Journal of Experimental Biological Sciences (Special issue):65-68.

Sibel T, Birol T (2007) Some physiological responses of drought stress in wheat genotypes with different ploidity in Turkiye. World Journal of Agriculture Science 3: 178-183.

Sinaki JM, Haravan EM, Rad AHS, Noormohammadi G, Zarei G (2007) The effects of water deficit during growth stages of canola (Brassica napus L.). American-Eurasian Journal of Agriculture and Environmental Science 2: 417-422.

Smiciklas KD, Mullen RE, Carlson RE, Knapp AD (1992) Soybean seed quality response drought stress and pod position. Agronomy Journal 84:166-170.

Sun R, Zhao B, Zhu L (2003) Effect of long-term fertilization on soil enzyme activities and its role in adjusting-controlling soil fertility. Plant Nutrition and Fertilizer Science 9:406-410.

Taize L, Zeiger E (2006) "Plant Physiology", 4th ed.; Sinauer Associates, Inc.: Sunderland, MA, USA.

Tawfik KM (2008) Effect of Water Stress in Addition to Potassium Application on Mungbean. Australian Journal of Basic and Applied Sciences 2: 42-52.

Taylor, AG, Moles JE, Kirkham NB (1982) Germination and seedling growth characteristics of three tomato species affected by water deficits. Journal of American Society of Horticulture 107: 282-285.

Tejada M, Hernandez MT, Garcia C (2009) Soil restoration using composted plant residues: Effect on soil properties. Soil and Tillage Research 102: 109-117.

Thapa G, Dey M, Sahoo L, Panda SK (2011) An insight into the drought stress induced alterations in plants. Biologia Plantarum 55: 603-613.

Verbruggen N, Hermans C (2008) Proline accumulation inplants: a review. Amino Acids 35: 753 759.doi:10.1007/s00726-008-0061-6.

Wahba HE, Motawe HM, Ibrahim AY, Mohamed AH (2007) The Influence of Amino Acids on Productivity of Urtica Pilulifera Plant. 3rd International Conference of Pharmaceutical and Drug Industries Division, National Research Council, Cairo

Wang GP, Hui Z, Li F, Zhao MR, Zhang J, Wang W (2010) Improvement of heat and drought on photosynthetic tolerance in wheat by accumulation of glycine betaine Plant Biotechnology Reports 4: 212-222.DOI 10.1007/s11816-010-0139-y.

Wesseling J, Stoof C, Ritsema C, Oostindie K, Dekker L (2009) The effect of soil texture and organic amendment on the hydrological behaviour of coarse textured soils. Soil use and management 25: 274283.DOI: 10.1111/j.1475-2743.2009.00224.x.

Willenborb CJ, Gulden RH, Jhonson EN, Shirtliffe SJ (2004) Germination characteristics of polymer-coat canola (Brassica napus L.) seeds subjected to moisture stress at different temperatures. Agronomy Journal 96: 786-791.doi:10.2134/agronj2004.0786.

Yamada M, Morishita H, Urano K, Shiozaki N, Yamaguchi-Shinozaki K, Shinozaki K, Yoshiba Y (2005) Effects of free proline accumulation in petunias under drought stress. Journal of Experimental Botany 56:1975-1981.doi: 10.1093/jxb/eri195.

Yokas I, Tuna AL, Burun B, Altunlu H, Altan F, Kaya C (2008) Responses of the tomato (Lycopersicon esculentum Mill.) plant to exposure to different salt forms and rates. Turkish Journal of Agriculture and Forestry 32: 319-329.

Zhang QT, Ahmed OAB, Inoue M, Saxena MS, InosakoK, Kondo K (2009) Effects of mulching on evapotranspiration, yield and water use efficiency of Swiss chard (Beta vulgaris L. var. flavescens) irrigated with diluted seawater. Journal of Food Agriculture \& Environment 7:650-654.

Zhang M, Duan L, Zhai Z, Li J, Tian X, Wang B, He Z, Li Z (2004) Effects of plant growth regulators on water deficit-induced yield loss in soybean. Proceedings of the 4th International Crop Science Congress, Brisbane, Australia. 